
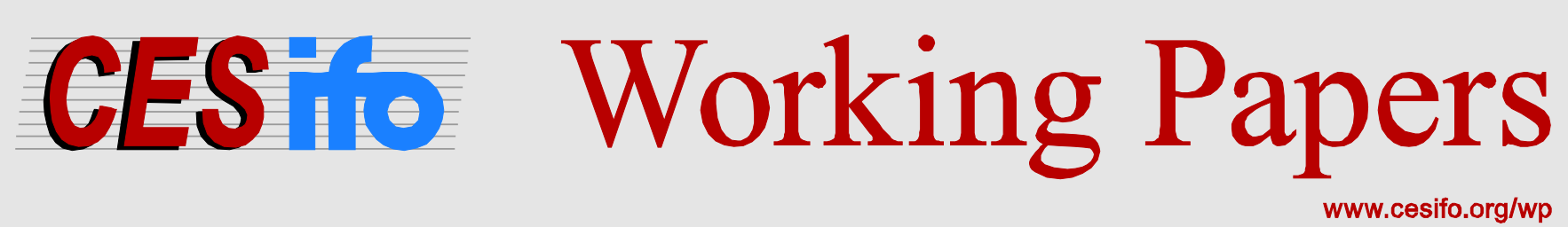

\title{
Supply Chain Finance and SMEs: Evidence from International Factoring Data
}

\author{
Marc Auboin \\ Harry Smythe \\ Robert Teh
}

CESIFO WORKING PAPER NO. 6039

CATEGORY 8: TRADE POLICY

August 2016

An electronic version of the paper may be downloaded

- from the SSRN website:

- from the RePEc website:

- from the CESifo website: WwW.SSRN.com

www.RePEc.org

www.CESifo-group.org/wp 


\title{
Supply Chain Finance and SMEs: Evidence from International Factoring Data
}

\begin{abstract}
The unbundling of trade across regions offers unique opportunities for SMEs to integrate into global trade notably through their involvement into supply-chains. With supply-chains shifting and expanding into new regions of the world, the challenge for SMEs to accessing financing remains an important one; in many developing and emerging market economies, the capacity of the local financial sector to support new traders is limited. Moreover, after the financial crisis, several global banks have "retrenched", for various reasons. In this context, supply-chain finance arrangements, and other alternative forms of financing such as through factoring, have proven increasingly popular among traders. This paper shows that factoring has a positive effect in allowing SMEs to access international trade, in countries in which it is available. Factoring also appears to be employed by firms involved in global supply chains. We employ for the first time data on factoring from Factor Chain International (FCI), the most extensive dataset on factoring available at the moment, for the period of 2008-2015. Using an instrumentation strategy, we identify a strong, stable effect of factoring on SMEs access to capital for some of the main traders in the world.
\end{abstract}

JEL-Codes: F130, F340, G210, G230.

Keywords: trade credit, financial crisis, trade.

\author{
Marc Auboin \\ Economic Research and Statistics Division \\ World Trade Organization \\ Rue de Lausanne 154 \\ Switzerland - 1211 Geneva 21 \\ marc.auboin@wto.org
}

Harry Smythe

Josef Korbel School of International

Studies / University of Denver

USA - Denver, CO 80210

hhh.smythe@gmail.com

\author{
Robert Teh \\ Economic Research and Statistics Division \\ World Trade Organization \\ Rue de Lausanne 154 \\ Switzerland - 1211 Geneva 21 \\ robert.teh@wto.org
}

The authors would like to thank Factors Chain International (FCI) for providing access to their data and helpful insights without which the present study could not have been completed. 


\section{INTRODUCTION}

For decades, trade finance had supported the expansion of international trade, and to some extent, had been taken for granted. Financial crises, in particular the Asian and Latin American crisis of the late 1990's and the great financial crisis of 2008-9, revealed that trade finance could be subject to serious disruptions, by contagion of other segments of the financial industry. Academic interest in the role of trade finance has developed in and around these periods. Several researchers were able to find robust evidence that shortages of trade finance during the great financial crisis had been one factor (albeit not the main) behind the "big trade collapse" of late 2008 to late $2009 .{ }^{5}$ More generally, they raised the likelihood of a wider link between financial conditions, trade credits and international trade flows (Amiti and Weinstein, 2011; Bricogne et al., 2012; Manova, 2013; Petersen and Rajan, 1997).

An important reason limiting the exploration of the impact of trade finance on trade has also been - and remains - the lack of consistent data on trade finance and its components. Relying on the relatively basic distinction between bank-intermediated trade finance and nonbank financing (including inter-company lending/credit), the Bank of International Settlements (BIS, 2014) confirmed recently that "there are no readily available data covering the global bank-intermediated trade finance market". Mixing several sources of data, the BIS estimated that annual flows of bank-intermediated finance were anywhere between \$6.5-8 trillion. Data on non-bank financing is not much easier to find. As noted by the BIS (2014 p.5), traders may not require bank's assistance for settling trade transactions; they may rely on one another's credit. The risk involved in extending supplier and buyers' credit can be mitigated through the use of credit insurance and other forms of trade risk offsets. The positive role of trade credit insurance on trade transactions was acknowledged by recent literature (Felbermayr and Yalcin, 2013; Felbermayr et al., 2012; Moser et al., 2008; Egger and Url, 2006).

Firms' trade financing options are enhanced by the possibility of discounting their receivables. Accounts receivable management (including discounting of short-term receivables through the assignment of invoices) is the primary activity of factoring companies. While receivables purchase and management has been in use for a long time, its expansion internationally is more recent. It seems to coincide with two economic phenomena: the expansion of global supply chains through the growth of open account trade involving ecosystems of small and medium-sized enterprises (SMEs) embedded in "made-in-the-world" product assembly processes; a tightening of bank lending since the great financial crisis of 2007-9, particularly for SMEs; no causality has yet been established, in part due to the lack of data.

According to practitioners surveys (ICC, 2015), bank-intermediated trade finance seems to have lost ground relative to inter-company lending in recent years. Financial techniques such as factoring have become increasingly popular; they solve a number of problems specific to traders involved in short-production cycles of intermediary goods or assembly lines. One major problem for SMEs involved in such cycle is the availability of working capital to finance the production of the next orders, including the payment of wages and production inputs. Unless exporting SMEs benefits from open account arrangements from their buyers (which would hence bear the credit risk until delivery, which is not that frequent), the immediate discounting of $30,45,90$ and up to 120 days receivables provides for an

${ }^{5}$ Eaton et al. (2011) find that demand shocks can explain $80 \%$ of the decline in trade and for some countries, like China and Japan, this share is a lot smaller. Hence, a significant share of the trade collapse remains to be explained. 
attractive proposition to deal with "high-frequency" orders from buyers, under a strong cashflow constraint. The attractiveness of factoring is also increased by the fact that it is a simple asset sale, and contrary to a loan, it does not create a liability for the company in question. ${ }^{6}$

This paper links for the first time the expansion of international factoring to that of global trade. Regressions indicate that the availability of factoring internationally has an impact on global trade trends - a $10 \%$ increase in global factoring may be responsible for $0.5 \%$ to $1 \%$ in increased trade. Our empirical strategy establishes the robustness of this relationship. We have been able to use the largest database currently available on factor-based transactions collected by the Members of Factor Chain International (FCI), the main association of factoring companies. The paper is structured as follows: Section 2 defines factoring. Section 3 introduces the dataset and gives summary statistics. Section 4 explains the empirical strategy. Section 5 then presents our empirical results. Finally, Section 6 gives a conclusion.

\section{WHAT IS FACTORING?}

Factoring is the buying and selling of accounts receivable to a factor, typically a bank or a specialized credit institution. All else being equal, a supplier would prefer to be paid for goods and services upon shipment while a buyer/debtor would prefer to pay for goods upon delivery and inspection of goods and services and often up to 30 to 90 days after receipt. To bridge this gap, the supplier can sell its accounts receivable (invoices) to a factor, less interest and service fees. The factor then receives payment from the buyer/debtor when the good or services are delivered/rendered, and the proceeds are used to pay down the advance payment made by the factor to the supplier. The factor assumes the credit and payment risk associated with the buyer. This is referred to as "non-recourse" factoring because the factor has no recourse against the supplier. Under "recourse" factoring, the factor holds a claim against the supplier in the event of default or failure to pay by the buyer/debtor. The factor may also withhold a reserve, calculated based on the historic dilution rate of the supplier, normally anywhere between $10 \%$ and $20 \%$, to be withheld but later paid to the supplier upon payment of the invoice by the buyer/debtor, less interest and service fees (Klapper, 2006). Generally speaking, factoring carries limited risk as the time between buying the invoice from the supplier and receiving the payment from the buyer tends to be short (in our data set, the longest term for any country is 120 days). ${ }^{7}$

In developed countries, factoring is most often performed on a "non-recourse" basis; however, higher quality exporting firms and lower quality importing firms are more likely to use "recourse" factoring (Sopranzetti, 1998; Muschella, 2003). According to Factor Chain International (FCI), the professional association of factoring companies, in 2014 the receivables finance industry generated $€ 2.35$ trillion in factoring transactions, mostly for

${ }^{6}$ This depends on whether the asset is purchased on a non-recourse versus a recourse basis, the latter not providing the seller/exporter any balance sheet enhancement e.g. receivables to cash conversion. Regarding the latter, the liability still exists if the seller/exporter produces an inferior product, or delivers the product late, resulting in a return of the product by the buyer and causing increased dilution risk which would shift the responsibility of repayment of the advance from the buyer back to the seller.

${ }^{7}$ In practice, the international factoring process involves all or part of the following steps: once the importer has placed an order with the exporter, the latter contacts a factor with details of the transaction; thus when the exporter ships the ordered good to the importers, the invoice is sent to the importer to pay the factor; the exporter assigns the account receivable to the factor; the factor advances the proceeds to the exporting firm, which will be the full amount, less the reserve established, fees and interest, or a previously determined percentage; the importing firm pays the factor; if there is a balance owed to the exporting firm, the factor pays the balance, less fees and interest (African Export-Import Bank). 
domestic trade (78\% of the total), and mostly generated by SMEs. The EU accounted for $65 \%$ of global transactions, mainly from domestic trade (intra-French trade; intra-German trade, etc.). According to FCI, SMEs account for $75 \%$ of the European Union's factoring sector, based on the number of clients that use the service. As the European Union accounts for $65 \%$ of the global receivables finance industry, it can be surmised that the majority of users globally are SMEs. As shown in the next sections, the cross-border share of factoring transactions is $28 \%$ and it has grown much faster than domestic factoring in recent years.

\section{LITERATURE}

The existing literature suggests that an absence of or weak access to finance can strongly inhibit formal SME development, regardless of the level of per capita income of countries. Market failures, notably in financial markets (be they financial crises or "information asymmetries"), fall disproportionally on SMEs, resulting in more credit rationing, higher costs of "screening" and higher interest rates from banks than larger enterprises (Stiglitz and Weiss, 1981; Beck and Demirgüc-Kunt, 2006). Credit constraints are particularly reflected in access to trade finance and in general working capital for the production of goods aimed at foreign markets. In modern supply chains, characterized by high volumes of orders (of parts and components) for exports towards global markets, obtaining cash-in-time for SMEs is key to continuing to produce and supply their larger buyers. Still, buyers typically pay their suppliers on 90 days (or more) terms. As a result, SMEs are in search for immediate cash to be able to pay the salaries and inputs necessary to fulfil their order. In this process, factoring can constitute a quick and efficient way to get immediate cash against invoice(s), notably for SMEs.

Still, the academic about the role, operations and impact of factoring, and supply chain finance in general, is also rather limited by the lack of previously available data. An initial batch of papers appeared in industrial organization and portfolio choice literatures of the mid1990 's, to explain the motives of factoring. Sopranzetti (1999) explained that receivable financing could mitigate underinvestment problems in smaller firms, while vertical integration and transaction cost reduction appeared to be major determinants for Smoth and Scnucker (1994). Sopranzetti (1998) discussed and tested the determinants motivating firms (sellers) using factoring to factor with or without recourse. As it turned out, sellers with a higher percentage of poor quality receivables (with a greater exposure to credit risk) tended to be restricted to factoring with recourse. Sellers with higher quality receivables could sell their claims without recourse, while intermediate quality receivables were handled both ways, depending on the assessment of risk.

A decade later, Klapper (2006) reflected on factoring patterns and its role for small and medium sized enterprises (SMEs), based mainly on domestic factoring data. The features making factoring a popular form of finance for SMEs were described: smaller firms received immediate cash against creditworthy receivables at a discount; unlike a loan, factoring did not increase firm liabilities; unlike other forms of working capital financing, it did not involve loan collateralization; factoring qualified as a full financial service including collection services, credit protection, and book-keeping of receivables.

In describing the characteristics of prevalent factoring (without recourse), Klapper highlighted that factoring was well suited for financing the receivables "from large or foreign firms when those receivables are obligations of buyers who are more creditworthy than the seller itself". This meant that large buyers in some industries (distributors, end-products/brand owners) may be the "cornerstone" of the factoring system, as they provide for great payment 
security, although it is noted that their strong market power may at times place the factor at a greater disadvantage. Another feature of the factoring market is that credit information, which is necessary to enforce factoring transactions and contractual arrangements, is an important condition for the market to develop - an observation made on data from 48 countries (at the time mostly domestic factoring data). This is an interesting observation as data (section below) from FCI seems to suggest that international factoring has mainly developed in developed countries markets, and in emerging market countries where credit bureaus exist.

In a section about the benefits and challenges to factoring in emerging markets, it is reminded that, a priori, developing and emerging market economies do not offer a more difficult environment for the expansion of factoring, relative to bank-intermediated bank credit. It had been found over a sample of 39 countries that countries with weaker legal environment tend to use more inter-firm lending than banking lending for the financing of trade, due to the difficulty to write and enforce loans contracts (Demirgüc-Kunt and Maksimovic, 2002). In other developing countries, the propensity for small firms to resort to uncollateralized lending may be higher, not the least because larger "anchor buyers" use their market power to refuse to pay until the quality of the merchandise delivered by smaller firms is ascertained (McMillan and Woodruff, 1999).

Still, according to Klapper, "the challenge faced by many SMEs in emerging markets is how to convert their accounts receivables to credit worthy customers into working capital financing. A bank loan secured by accounts receivable, which is the primary source of SME financing in the US, is often unavailable in emerging markets". Klapper mentions other obstacles, such as the absence of laws allowing lenders "to secure intangible/floating assets", and "judicial system that are quick and efficient to enforce such contracts". Other tax and legal issues arise in emerging markets.

Soufani (2002) looked at the determinants of factoring in the United Kingdom. As reported by his paper, "in the UK corporate sector about $80 \%$ of daily business transactions are on credit terms", either (domestic and international) trade credit or bank credit. Econometric tests support the view that the less the availability of credit by banks, the higher the usage of factoring. However, while the evidence suggests that factoring is mainly use by SMEs, the smallest and youngest firms would not have access to it due to a lack of experience and "track record" - so like bank financing low levels of business activity can be an obstacle to access finance. Factoring is used only at a certain stage of the firm's development once it has attained a certain level of confidence and a proven track record to produce quality products and/or services, and experience of the invoicing and payment system. Another interesting piece of information is that users of factoring tend to be found in the manufacturing and associated industries.

\section{DATA}

\section{FCI Data}

Factor Chain International (FCI) is the main global network of about 410 factoring companies and banks engaged in factoring activities in over 90 countries. FCI collect data from network members on both domestic and international factoring transactions. FCI data is the most comprehensive source of information on factoring transactions, with details by subcategory of factoring transaction (export factoring with and without recourse, import factoring, two-factor), and by country and region. As indicated in Section II, factoring is mostly used in domestic trade but its use in international trade is the fastest, in particular since 2008. FCI 
international transactions for 2014 totalled over $\$ 500$ billion, from 70 countries. The average transaction is less than $\$ 50,000$ - such transactions may involve one or several invoices. For this study, FCI provided its original data set of 70 countries, although complete observations only exist for 49 of them for the period 2008-2014 (included).

Among the 49 countries, 35 are high income countries, 9 are upper middle income countries, and 5 are lower-middle income countries according to the World Bank's country classification by income groups. ${ }^{8}$ Reflecting the very recent expansion of international factoring in many countries, each country appears for an average of 5.8 years (out of 6). Altogether, the 49 countries account for a share of $93 \%$ of global trade. It includes the United States, China, the main members of the European Union, Brazil, India, Russia, Turkey, the main members of the ASEAN, countries of the Middle-East, and a few African countries. The exact list of countries included in our sample can be found in Table A.1 in the Appendix.

One important limitation for empirical work is that data on total international factoring is only available annually, which altogether limits the number of observations for data analysis. However, directional data for one important component, two-factor transactions (that is factoring transactions involving both an export and an import factor) is available monthly and quarterly. This component accounts for about $15 \%$ of total international cross border factoring transactions. Other forms of trade finance, such as Berne Union data (below) is available quarterly. Importantly, the respective profiles of total factoring transactions, on the one hand, and its two-factor component, on the other, are very similar. In fact, the growth trends of the annual cross border factoring figures are predictive, as the former is generally growing at a similar rate as the cross border two-factor figures reported monthly, even though it is a relatively small subset of the former. Therefore, as explained in the empirical strategy section, a first set of analysis is done with the overall, annual data - not the least because annual data allows working with both factoring transactions, and other trade finance data (Berne Union, see below). Thus, we worked with two-factor data - with more numerous observations but lower transaction "coverage", with a view to verify some of the analysis done with annual data, which cover larger amounts of trade finance with a lower number of observations.

\section{Other trade finance data}

Another important source of data used in this paper is that of the Berne Union. As explained in Auboin and Engemann (2013), Berne Union data is at the present moment the best possible proxy for overall trade credit because it includes a consistent data series of insured trade credit flows, including both bank-intermediated credit (such as letters of credit) and intercompany loans (such as suppliers credit). The Berne Union is the international trade association for credit and investment insurers having more than 70 members, which include the world's largest private credit insurers and public export credit agencies. The volume of trade credit insured by members of the Berne Union covers more than $10 \%$ of international trade (Berne Union, 2010), that is well over $\$ 2$ trillion annually. Data is available quarterly. The Berne Union dataset includes both data on short-term (ST) i.e. of less than one year, and mediumand long-term transactions (MLT). Short-term transactions account for over $80 \%$ of total transactions, so our analysis focused on it.

\section{Trade data}

8 Countries are classified according to their gross national income (GNI). See http://data.worldbank.org/about/country-classifications/country-and-lending-groups (accessed 12.11.2015). 
Trade data used in this paper is directly extracted from the WTO database. It includes cross-country data for all countries in the world and sectoral data for most of them. SME data, used in the equations is the share of SMEs in each country's trade, according to standard SME definition (less than 250 employees), albeit the SME share is applied to overall and sector trade ex-post, as the SME share of trade for each sector is not a piece of information available for most countries (see Table A. 2 in the Appendix). Regarding trade flows, a high level of sectoral disaggregation is available at sectoral and country-level, annually and monthly. For more details about the WTO database, please consult in www.wto.org, the International Trade Statistics section.

\section{EMPIRICAL STRATEGY}

As indicated above, the average factor transaction, which generally contains several receivables, is around $\$ 50,000$ which suggests that SMEs are large users of factoring. Countries with the largest volumes of factoring transactions are also those involved into international supply chain trade (China, Germany, France, Chinese Taipei), also raising the presumption that international factoring can be linked to SME trade. The strategy is hence to link the growth of international factoring, a relatively recent phenomenon, and SME trade - in an environment marked by the retrenchment of bank intermediated finance (as a direct result from the postfinancial crisis environment). Another objective is to verify, as possible, whether international factoring comes as a complement or a substitute of other trade finance instruments, which are proxied by Berne Union data. The first set of analysis is conducted with available annual data, using the logs of FCI factoring transaction data, Bern Union Data as a proxy for international trade credit, WTO trade statistics on yearly merchandise trade times the SME share for each country used, and the Average Days Until Payment (also from the FCI data) as a proxy for risk (the longer the payment is due, the higher the risk). The models are specified just below. In a second stage, we use more partial data on two-factor transactions, but which log is in value close (albeit somewhat smaller) to total factoring transactions.

\section{V.1 Main model (annual data)}

For our first principal specification, we regress the natural logarithm of international trade of SMEs against the natural logs of working capital obtained by discounting invoices under factoring transactions and the measure of short term trade credit obtained from Berne Union data. This is shown in equation (1). The intuition is that factoring represents an additional opportunity for SMEs to finance their trade transactions (and eventually production), other than the traditional trade finance instruments (bank-intermediated and inter-credit) which form the bulk of insured (traditional) trade credit covered by Berne Union members. Factoring is not necessarily a substitute for traditional trade credit since traditional trade credit offer other advantages, in particular a higher level of security for transactions, with costs and fees related to structuring and insuring that credit. The intuition is therefore that factoring and traditional trade credits are not negatively correlated. Factoring represents a more direct way of obtaining cash against invoice. It may in cases work as an alternative, when the SME is so small that it may not qualify for bank credit. ${ }^{9}$

${ }^{9}$ While it could be an alternative, it is not a perfect substitute since, for example, under factoring the creditor does not hold a claim on the merchandise, unlike in a letter of credit. Still, it is relatively user-friendly, as letters of credit are labour and time-intensive. Both factoring and structured trade credit are used in supply chains according to industry representatives. The earlier offers the advantage of speed and high-frequency involved in 
Here $\operatorname{Ln}($ SME Trade) it is the natural logarithm of trade (sum of exports and imports) attributable to the SMEs of country $i$ in year $t$; $\operatorname{Ln}($ Factoring) it is the value of total factoring in country $i$ in year $t$; $\operatorname{Ln}(C r e d i t)_{\text {it }}$ is the value of trade credit in country $i$ in year $t ; \mu_{\mathrm{i}}$ are the country-specific fixed effects; and $\epsilon_{\text {it }}$ is the error term. The betas are the regression coefficients where $\beta_{1}$ is the elasticity of SME trade with respect to the volume of factoring and $\beta_{2}$ is the elasticity of SME trade with respect to the amount of trade credit. We expect $\beta_{1}$ and $\beta_{1}$ to both be positive, i.e. factoring and trade credit enable SMEs to engage in more trade and they are complementary rather than substitutes, and statistically significant.

As an alternative, we have equation (2) which incorporates the notion (and impact) of risk of factoring to the previous specification to examine whether this affects the total amount of merchandise trade in context of the other explanatory variables. At the moment, the best available proxy for risk in factoring transactions is payment delays, which is the average number of days for payments due to the factor by the buyer. FCI provides information on the average number of days until payments, for each country. An increase in average days in payment, hence of risk, is expected to be negatively correlated to trade.

$\operatorname{Ln}(\text { SME Trade })_{\text {it }}=\delta_{0}+\delta_{1} \operatorname{Ln}(\text { Factoring })_{\text {it }}+\delta_{2} \operatorname{Ln}(\text { Credit })_{\text {it }}+\delta_{3} \operatorname{Ln}(\text { Average Delay })_{\mathrm{it}}+\mu_{\mathrm{i}}+\epsilon_{\mathrm{it}}$

\section{V.2 Testing the factoring and trade relationship with directional data and quarterly data}

In this second stage, directional data (country pairs) between countries $\mathrm{i}$ and $\mathrm{j}$ at time $\mathrm{t}$ is used to regress factoring against SME trade (equation 3), with lags for factoring and SME trade added as dependent variables, whereas:

$\operatorname{Ln}(\operatorname{SME~Trade~})_{\mathrm{it}}=\beta_{8}+\beta_{9} \operatorname{Ln}\left(\right.$ Factoring $\left._{\mathrm{it}}\right)+\mu_{\mathrm{ij}}+\mathrm{w}_{\mathrm{it}}$

As indicated above, quarterly data and country pairs are available only for a fraction of factoring statistics. Unfortunately, it is not available for total factoring because some key components of factoring transactions are only available annually. However, the profiles of total factoring (annual data) and two-factor (quarterly) look alike, although in regressions the coefficients for two-factor transactions came up as significant, albeit somewhat smaller. This was not surprising as two factor transactions are in total about a quarter of the value of total factoring; however, in the course of the regressions' process, coefficients started to increase as the number of observations was being reduced to take into account only the largest country pairs. In other words, the higher SME bilateral trade (pairs such as China-Chinese Taipei; France-Italy), the higher the amount of two-factor transaction, and the more significant this form of factoring in explaining such intense bilateral trade relationship. Directional data was disaggregated into quintiles and progressively regressed from $100 \%$ of all transactions to the largest $20 \%$ of transactions. The results are reported in Table 2.

seller and buyer relationship. The latter offers strong collateral control. Factoring is not as available around the world as it is for overall trade credit, though. In any case, the intuition behind the figures is that an increase in factoring increases global supply of credit and liquidity for exporters (in addition to other facilities), which altogether increase global merchandise trade total of SMEs. 


\section{RESULTS}

\section{Main specification}

\section{Linking factoring and credit to SME integration into global trade. (Table 2)}

Table 1 contains the results of our main specification for Equation (1) and (2). Equation (1) and (2) are estimated using generalized least squares regression, random effects instrumental variable estimate (RE $\beta$ ) and fixed effects instrumental variable estimator (FE $\beta$ coefficient). Using RE IV and FE IV we can control for observed and unobserved time constant country effects, such as institutions. We use the Hausman test to check whether RE $\beta$ or FE $\beta$ should be our preferred specification. In all specifications we use heteroscedasticity - robust standard errors, taking into account the time-series structure of our data (see next section of robustness).

Table 1 shows that total factoring and trade credit have a strong explanatory effect on SME's trade. The estimated elasticity of factoring transactions is 0.112 , that is for any additional 1 percent of factoring transaction available, SME trade would be increased by 0.112 percent.

The estimated elasticity of 0.32 to 0.38 for trade credit (Berne Union) is roughly comparable albeit somewhat smaller than in Auboin and Engemann (2014). The difference in coefficients is not a surprise, as Berne Union data cover a significant volume and wide variety of other trade finance instruments, including letters of credit and the like, pre-shipment lending and various types of inter-company trade loans (supplier and buyer's credit for example). Both factoring and trade credit are positively correlated to SME trade, suggesting that they are complements rather than substitutes, both contributing to support international trade flows.

The results of estimating equation 2, which includes payment delays as a measure of financial risk, shows that risk has a small, negative but statistically significant impact upon SME trade. A one percent increase in the number of days that payments are delayed decreases SME trade by a little less than two-thousandth of a percent. The coefficients for factoring and trade credit are unaffected. 
Table 1: SME Trade and Factoring Regression Results

Table 1

\begin{tabular}{|c|c|c|}
\hline \multicolumn{3}{|l|}{ Equation 1} \\
\hline Variables & $\begin{array}{c}\text { (A) } \\
\text { Random } \\
\text { Effects }\end{array}$ & $\begin{array}{c}\text { (B) } \\
\text { Fixed Effects }\end{array}$ \\
\hline $\operatorname{Ln}(\text { Factoring })_{\text {it }}$ & $\begin{array}{l}0.1115^{* * *} \\
(0.02886)\end{array}$ & $\begin{array}{c}0.01071 * * * \\
(0.02881)\end{array}$ \\
\hline $\operatorname{Ln}(\text { Credit })_{\text {it }}$ & $\begin{array}{c}0.3833^{* *} \\
(0.1531)\end{array}$ & $\begin{array}{c}0.3209 * * \\
(0.1454)\end{array}$ \\
\hline Constant & $\begin{array}{c}13.475 * * * \\
(3.1246)\end{array}$ & $\begin{array}{c}14.973 * * * \\
(2.9602)\end{array}$ \\
\hline $\begin{array}{l}\text { No. of Observations } \\
\text { R-squared } \\
\text { Number of Countries } \\
\text { Wald Chi2 statistic (1) } \\
\text { F-statistic }(1,943)\end{array}$ & $\begin{array}{c}286 \\
0.7349 \\
49 \\
65.22 \\
-\end{array}$ & $\begin{array}{c}286 \\
0.7309 \\
49 \\
- \\
156.44\end{array}$ \\
\hline \multicolumn{3}{|l|}{ Equation 2} \\
\hline Explanatory Variables & $\begin{array}{c}\text { (A) } \\
\text { Random } \\
\text { Effects }\end{array}$ & $\begin{array}{c}\text { (B) } \\
\text { Fixed Effects }\end{array}$ \\
\hline $\operatorname{Ln}(\text { Factoring })_{\mathrm{it}}$ & $\begin{array}{c}0.1068 * * * \\
(0.02801)\end{array}$ & $\begin{array}{c}0.1016 * * * \\
(0.02786)\end{array}$ \\
\hline $\operatorname{Ln}(\text { Credit })_{\text {it }}$ & $\begin{array}{c}0.3725^{* *} \\
(0.1502)\end{array}$ & $\begin{array}{c}0.3104 * * \\
(0.1414)\end{array}$ \\
\hline $\operatorname{Ln}(\text { Delay })_{\text {it }}$ & $\begin{array}{c}-0.001776^{* * *} \\
(0.0005421)\end{array}$ & $\begin{array}{c}-0.001868 * * * \\
(0.0006053)\end{array}$ \\
\hline Constant & $\begin{array}{c}13.865 * * * \\
(3.1139)\end{array}$ & $\begin{array}{c}15.385^{* * *} \\
(2.9300)\end{array}$ \\
\hline Number of observations & 283 & 283 \\
\hline R-squared & 0.7389 & 0.7356 \\
\hline Number of Countries & 49 & 49 \\
\hline Wald Chi2 & 106.69 & \\
\hline $\mathrm{F}$ & & 27.279 \\
\hline
\end{tabular}


Table 2 reports regression results for equations 3 and 4 . As reported below, we initially found smaller coefficients for Log (Factoring) than in equations 1 and 2 due to the lower value of factor transactions (limited to two-factor) and the disaggregated nature of directional data compared to the global factors flows; however, the [explanatory power of factoring remained strong and robust so we decided to look at country pairs in greater detail.

Table 2

\begin{tabular}{|lcc|}
\hline Equation 3 & & \\
\hline Variables & RE $\beta$ & FE $\beta$ Coefficient \\
\hline & Coefficient & \\
Log(Factoring) & & $0.0102488^{* * *}$ \\
Std. Err. & $0.0150216 * * *$ & $(0.0037882)$ \\
Constant & $(0.0038367)$ & $8.865278^{* * *}$ \\
Std. Err. & $8.689598 * * *$ & $(0.026327)$ \\
& $(0.0362654)$ & Fixed-Effects (within) \\
Estimation Method & & Regression \\
& GLS & Robust FE \\
Observations & Robression & 3,795 \\
R-squared & 3,795 & 0.1723 \\
Unique Directions & 0.1723 & 944 \\
Wald Chi2 statistic $(1)$ & 944 & - \\
F-statistic $(1,943)$ & 15.33 & 7.32 \\
Prob $>$ test statistic & - & 0.0000 \\
\hline Robust standard errors in parentheses & 0.0000 & \\
*** $\mathrm{p}<0.01, * * \mathrm{p}<0.05, * \mathrm{p}<0.1$ & &
\end{tabular}

Table 3 contains the results of the progressively intensifying the directional trade relationship between two countries. We find that the relatively more intense the trading relationship between two countries is, the closer the relationship approaches the global yearly estimate in Table 1. Table 3 shows that as we move from $100 \%$ of all transactions (bottom right) to just the top $20 \%$ of country (boxed cell) we see that the coefficient approaches that of the global coefficient in Table 1.

The intuition makes sense as the global SME pattern is dominated by large economies with many SME exporters, and the more intense the trading pattern is the more closely it resembles the global data trend. Only two intersections are statistically insignificant, where $\log$ (Factoring) is $100 \%$ and $80 \%$, and Log (SME Trade) is $20 \%$. Even when we ignore those two data points the larger overall trend still holds that as the directional data intensifies, the coefficient approaches that of the global pattern. Of the 994 country directional pairs, 86 directional pairs account for top $20 \%$ of both SME Trade and Factoring. A breakdown of the number of directional pairs and the number of observations of each quintile is available in the appendix (see Table A.3). 
Table 3

\begin{tabular}{|c|c|c|c|c|c|c|}
\hline & \multicolumn{5}{|c|}{ Log (SME Trade) } \\
\hline & & $20 \%$ & $40 \%$ & $60 \%$ & $80 \%$ & $100 \%$ \\
\hline \multirow{5}{*}{$\begin{array}{c}\text { Log } \\
\text { (Factoring) }\end{array}$} & $20 \%$ & $\begin{array}{c}\mathbf{0 . 0 9 7 7 0 8 7} \\
(0.023752) \\
P>|t|=0.000\end{array}$ & $\begin{array}{l}\mathbf{0 . 0 8 0 0 6 8 6} \\
(0.0206689) \\
P>|t|=0.000\end{array}$ & $\begin{array}{l}\mathbf{0 . 0 7 3 7 7 6 8} \\
(0.0193979) \\
P>|t|=0.000\end{array}$ & $\begin{array}{l}\mathbf{0 . 0 7 1 7 6 8 4} \\
(0.0185266) \\
P>|t|=0.000\end{array}$ & $\begin{array}{l}\mathbf{0 . 0 7 1 6 2 8 8} \\
(0.0184185) \\
P>|t|=0.000\end{array}$ \\
\hline & $40 \%$ & $\begin{array}{c}\mathbf{0 . 0 7 1 2 2 0 5} \\
(0.018501) \\
P>|t|=0.000\end{array}$ & $\begin{array}{c}\mathbf{0 . 0 6 2 3 2 1 5} \\
(.0142267) \\
P>|t|=0.000\end{array}$ & $\begin{array}{l}\mathbf{0 . 0 5 5 0 0 9 8} \\
(0.0122809) \\
P>|t|=0.000\end{array}$ & $\begin{array}{l}\mathbf{0 . 0 6 1 8 9 3 1} \\
(0.0117919) \\
P>|t|=0.000\end{array}$ & $\begin{array}{l}\mathbf{0 . 0 6 3 2 7 9 8} \\
(0.0114557) \\
P>|t|=0.000\end{array}$ \\
\hline & $60 \%$ & $\begin{array}{l}\mathbf{0 . 0 4 2 2 5 1 8} \\
(0.0139198) \\
P>|t|=0.003\end{array}$ & $\begin{array}{c}\mathbf{0 . 0 4 1 9 1 6 6} \\
(0.0099506) \\
P>|t|=0.000\end{array}$ & $\begin{array}{l}\mathbf{0 . 0 4 3 7 1 1 5} \\
(0.0090459) \\
P>|t|=0.000\end{array}$ & $\begin{array}{l}\mathbf{0 . 0 4 9 1 8 4 7} \\
(0.0083711) \\
P>|t|=0.000\end{array}$ & $\begin{array}{c}\mathbf{0 . 0 4 8 8 2 0 3} \\
(0.080688) \\
P>|t|=0.000\end{array}$ \\
\hline & $80 \%$ & $\begin{array}{l}\mathbf{0 . 0 2 2 6 4 8 4} \\
(0.0116904) \\
P>|t|=0.054\end{array}$ & $\begin{array}{c}\mathbf{0 . 0 2 5 4 8} \\
(0.0082126) \\
P>|t|=0.002\end{array}$ & $\begin{array}{l}\mathbf{0 . 0 2 7 1 7 6 6} \\
(0.0071714) \\
P>|t|=0.000\end{array}$ & $\begin{array}{c}\mathbf{0 . 0 3 2 6 9 8 2} \\
(0.0063732) \\
P>|t|=0.000\end{array}$ & $\begin{array}{l}\mathbf{0 . 0 3 0 6 2 7 6} \\
(0.0060423) \\
P>|t|=0.000\end{array}$ \\
\hline & $100 \%$ & $\begin{array}{c}\mathbf{0 . 0 8 3 9 9 1} \\
(0.0074877) \\
P>|t|=0.264\end{array}$ & $\begin{array}{l}\mathbf{0 . 0 1 6 9 0 4 6} \\
(0.0054116) \\
P>|t|=0.002\end{array}$ & $\begin{array}{l}\mathbf{0 . 0 1 3 4 9 8 6} \\
(0.0043063) \\
P>|t|=0.002\end{array}$ & $\begin{array}{l}\mathbf{0 . 0 1 4 4 0 7 7} \\
(0.0039867) \\
P>|t|=0.000\end{array}$ & $\begin{array}{l}\mathbf{0 . 0 1 0 2 4 8 8} \\
(0.0037882) \\
P>|t|=0.007\end{array}$ \\
\hline
\end{tabular}

\section{ROBUSTNESS CHECKS}

In all four specified models we checked the robustness of the model by testing for the possible non-stationarity of the data, testing for possible endogeneity of the explanatory variables, and introducing a dummy variable for the year of financial crisis, 2009.

\section{Non-stationarity of the data}

One possible concern with the estimation results is non-stationarity of the time series data. As is well known, if variables are non-stationary, the estimated means and variances are inconsistent and tests of significance will be unreliable. Testing for stationarity of the trade, factoring and trade credit data, we cannot reject the hypothesis that they contain unit roots (the results of the tests appear in Table A.4 in the appendix). However, the data on average days of delay appear stationary. Thus, with this exception, we transform all the other variables by taking their first-differences, i.e. which will approximate the annual growth rate of the variables and run equations (1) and (2) on the first differenced data.

The results are shown in Table 4. Controlling for possible stationarity, Table 4 validates our previous result that factoring and trade credit have strong positive effects on SME's trade. The estimated elasticities are even bigger than when data in levels form were used. The elasticity of SME trade growth with respect to growth in factoring is around 0.18 and about 0.76 with respect to trade credit growth. Both factoring and trade credit growth are positively correlated to the growth of SME trade confirming that factoring and trade credit are complements rather than substitutes. Matters are less clear when we add the average days of delay (see equation 2 in Table 4). It is not statistically significant although the first difference of factoring and trade credit continue to be statistically significant and quite large. 
Table 4: SME Trade and Factoring Regression Results, first-differenced data

Table 4

\begin{tabular}{|c|c|c|}
\hline \multicolumn{3}{|l|}{ Equation 1} \\
\hline Variables & $\begin{array}{c}\text { (A) } \\
\text { Random } \\
\text { Effects }\end{array}$ & $\begin{array}{c}\text { (B) } \\
\text { Fixed Effects }\end{array}$ \\
\hline $\mathrm{dLn}(\text { Factoring })_{\text {it }}$ & $\begin{array}{l}0.1863 * * \\
(0.8497)\end{array}$ & $\begin{array}{l}0.1767 * * \\
(0.08289)\end{array}$ \\
\hline $\mathrm{dLn}(\text { Credit })_{\mathrm{it}}$ & $\begin{array}{c}0.7619 * * * \\
(0.1825)\end{array}$ & $\begin{array}{c}0.7662 * * * \\
(0.2007)\end{array}$ \\
\hline Constant & $\begin{array}{l}-0.004214 \\
(0.02534)\end{array}$ & $\begin{array}{c}-0.003820 \\
(2.9602)\end{array}$ \\
\hline No. of Observations & 264 & 264 \\
\hline R-squared & 0.7041 & 0.704 \\
\hline Number of Countries & 48 & 48 \\
\hline Wald Chi2 statistic (1) & 52.67 & - \\
\hline F-statistic $(1,943)$ & - & 24.112 \\
\hline \multicolumn{3}{|l|}{ Equation 2} \\
\hline Explanatory Variables & $\begin{array}{c}\text { (A) } \\
\text { Random } \\
\text { Effects }\end{array}$ & $\begin{array}{c}\text { (B) } \\
\text { Fixed Effects }\end{array}$ \\
\hline $\mathrm{dLn}(\text { Factoring })_{\text {it }}$ & $\begin{array}{c}0.1883 * * * \\
(0.09603)\end{array}$ & $\begin{array}{c}0.1761 * \\
(0.09096)\end{array}$ \\
\hline $\mathrm{dLn}(\text { Credit })_{\mathrm{it}}$ & $\begin{array}{c}0.7511 * * * \\
(0.1502)\end{array}$ & $\begin{array}{c}0.7420^{* * * *} \\
(0.2294)\end{array}$ \\
\hline $\operatorname{Ln}(\text { Delay })_{\text {it }}$ & $\begin{array}{c}-0.006110 * * * \\
(0.02078)\end{array}$ & $\begin{array}{c}-0.06773 * * * \\
(0.09689)\end{array}$ \\
\hline Constant & $\begin{array}{c}0.02978 \\
(0.06781)\end{array}$ & $\begin{array}{c}0.2244 \\
(0.3045)\end{array}$ \\
\hline Number of observations & 226 & 226 \\
\hline R-squared & 0.7025 & 0.6983 \\
\hline Number of Countries & 45 & 45 \\
\hline Wald Chi2 & 52.16 & \\
\hline $\mathrm{F}$ & & 15.933 \\
\hline
\end{tabular}




\section{Testing for endogeneity}

Another potential pitfall of the estimation is endogeneity of the explanatory variables. This could occur for example if the volume of SME trade (the dependent variable) affects the amount of factoring or trade credit that SMEs will demand (the explanatory variables). The greater the value of SME trade, the more these firms will demand factoring or trade credit. In this case, the regressions will produce inconsistent estimates. We test for possible endogeneity in two ways: through the use of Granger-causality tests (Granger, 1969) and the Hausman test.

\section{Granger causality tests}

We run a Granger causality test to determine whether the dependent variable "Granger-causes" the explanatory variables (factoring and trade credit). The results of the Granger causality tests on both the levels and first differenced data are shown in Table A.5 in the appendix. They show that there is no Granger causality from the dependent variable to the explanatory variables and thus support the claim that endogeneity is not a problem in the estimation.

\section{Hausman testing}

Alternatively, we use the testing for endogeneity as proposed by Hausman (1978; 1983), we find that $\mathrm{p}=0.0014$ and 0.0016 for each model (Equations 1 and 2 respectively). Values of p> 0.05 would have indicated random effects specification, but as our values are well below that threshold, we determined to use a fixed effects model, and to specify a robust model to correct for homoscedasticity. The Hausman test for equation 3 yielded similar values of $\mathrm{p}=0.000$, since these values are lower than the accepted thresholds of $\mathrm{p}=0.05$, a fixed effects model was selected, and a robust fixed effects model specified to correct for homoscedasticity.

The crisis dummy variable was specified as Crisis Year*Log Factoring. The results are in Table 4 below, but in general we find there is little change in the coefficients, the largest sensitivity was 0.41 in the Pay Delay model, otherwise the sensitivity in the variables of interest was between 0.07 and 0.40 . Our results maintain their robust explanatory power, particularly because in the variables of interest generally do not show a large degree of sensitivity to the introduced dummy variable. 
Table 4

\begin{tabular}{|c|c|c|c|c|}
\hline & Variable & $\begin{array}{c}\text { Original } \\
\text { Coefficient }\end{array}$ & $\begin{array}{l}\text { Robustness } \\
\text { Check } \\
\text { Coefficient }\end{array}$ & Sensitivity \\
\hline \multirow{3}{*}{$\begin{array}{c}\text { Equation } \\
1\end{array}$} & $\log ($ Factoring $)$ & $0.1070949 * * *$ & $0.0650787 * *$ & 0.39 \\
\hline & $\log ($ Credit $)$ & $0.3208703 * *$ & $0.2122737 * *$ & 0.34 \\
\hline & Constant & $6.502605 * * *$ & $7.964024 * * *$ & -0.22 \\
\hline \multirow{4}{*}{$\begin{array}{c}\text { Equation } \\
2\end{array}$} & $\log ($ Factoring $)$ & $0.1015695 * * *$ & $0.0614792 * * *$ & 0.39 \\
\hline & Log(Credit) & $0.3103903 * * *$ & $0.2094998 * * *$ & 0.33 \\
\hline & Pay Delay & $-0.0008112 * *$ & $-.0004811 * *$ & -0.41 \\
\hline & Constant & $6.681799 * * *$ & $8.041056 * * *$ & -0.20 \\
\hline \multirow{3}{*}{$\begin{array}{c}\text { Equation } \\
3\end{array}$} & $\log ($ Factoring $)$ & $0.0102488 * * *$ & $0.0076613 * *$ & 0.25 \\
\hline & Constant & $8.865278^{* * *}$ & $8.901581 * * *$ & 0.00 \\
\hline & \multicolumn{4}{|c|}{$* * * \mathrm{p}<0.01, * * \mathrm{p}<0.05, * \mathrm{p}<0.1$} \\
\hline
\end{tabular}

\section{IS FACTORING RELATED TO GLOBAL SUPPLY CHAINS?}

Before we conclude, we examine the conjecture that the firms who use factoring are part of global supply chains and then provide some statistical evidence to support the hypothesis. We test the claim that the factoring network is associated with the global supply chain network. We use bilateral trade in "parts and accessories", averaged over the 2009-14 period, as a proxy for involvement in the global supply chain network ${ }^{10}$ and bilateral factoring volumes, averaged over the 2009-14 period, to represent the factoring network. The use of trade in intermediates to proxy for GVC related trade is pretty standard in the trade literature (Yi, 2003).

For the purpose of our statistical analysis, each network is represented by a square matrix. Note that since the data are dyadic, the observations in each matrix are not independently distributed and so the usual estimates of standard errors are inconsistent. To produce consistent estimates of the correlation between the two networks, we need to proceed in two steps (Hanneman and Riddle, 2005). First, we compute the correlation coefficient between corresponding cells of the matrices of bilateral trade and bilateral factoring volumes. Call this the observed correlation. In the second step, we randomly permute rows and columns

${ }^{10}$ This category of merchandise goods is part of the Broad Economic Classification (BEC) used to organize trade statistics in three basic classes of goods: capital, intermediate and consumption goods. See http://unstats.un.org/unsd/class/intercop/expertgroup/2011/AC234-25.PDF. 
of one matrix and recompute the correlation. This is performed several thousand times in order to generate a distribution of correlation coefficients under the null hypothesis of no relationship between the networks. We then calculate the proportion of times that the correlation is larger than or equal to the observed correlation calculated in step 1 . The lower this proportion the greater support there is for the hypothesis of a relationship between the networks, since the observed correlation is unlikely to have occurred by chance. The result of the procedure is shown in Table 5 for various numbers of random permutations (ten thousand, twenty thousand and fifty thousand). We present the results when we adjust the bilateral trade matrix by the share of SMEs in total trade and when we do not perform this adjustment. In either case, the correlation between factoring volumes and GVC trade is positive and large, 0.41 and 0.31 respectively, and statistically significant at the $5 \%$ and $1 \%$ level respectively suggesting a strong positive link between the two networks.

Table 5: Quadratic Assignment Procedure (QAP) Correlation between Factoring and Global Supply Chains

A. Bilateral trade adjusted for SME Share:

\begin{tabular}{|l|r|r|r|}
\hline Correlation & $0.408^{* *}$ & $0.408^{* *}$ & $0.408^{* *}$ \\
\hline p value & 0.045 & 0.044 & 0.043 \\
\hline Number of random permutations & 10,000 & 20,000 & 50,000 \\
\hline
\end{tabular}

B. Bilateral trade not adjusted for SME Share:

\begin{tabular}{|l|r|r|r|}
\hline Correlation & $0.308^{* * *}$ & $0.308^{* * *}$ & $0.308^{* * *}$ \\
\hline p value & 0.006 & 0.005 & 0.005 \\
\hline Number of random permutations & 10,000 & 20,000 & 50,000 \\
\hline
\end{tabular}

Legend: ${ }^{* *}$ Significant at the $5 \%$ level; ${ }^{* * *}$ significant at the $1 \%$ level.

\section{CONCLUSIONS}

This paper establishes a reasonably strong causal link between factoring and trade credit, on the one hand, and trade flows, through almost a full cycle (from the upswing of 2007 to 2014). Using data from Factor Chain International, both annual and quarterly (the later for country pairs), we find that a $1 \%$ increase in factoring (availability) granted globally, and to a country in the case of country pair analysis (for the top $20 \%$ of country pairs generating the largest volumes of trade), lead to a $0.1 \%$ increase in real trade flows. The coefficient for trade credit are very close to those $(1 \%$ increase in trade credit granted to a country leads to a $0.4 \%$ increase in real trade flows, although this is not surprising using the same database as Auboin and Engemann (2013), although using it for a longer period).

We also find that the correlation between factoring volumes and GVC trade is positive and large, 0.41 and 0.31 respectively, and statistically significant at the 5\% and $1 \%$ level respectively suggesting a strong positive link between the two networks.

There are several avenues for future work on factoring. First, more extensive quarterly data, for factoring transactions as a whole (not only one, even if major, components), would be needed to be able, on the micro-side, to know more about the determinants, the choice between 
the different sub-instruments of trade finance and the company-impacts. For this, transactionlevel data would also be needed. Transaction-level data would be also important to analyse inter-firm credit patterns, which are important to understand supply-chain financing arrangements. This would in particular help understand how the (short or long) supply of financing in supply-chains may eventually have an impact on production order and sharing within these supply-chains, thereby linking the "vertical specialisation" and its determinants/constraints. 


\section{BIBLIOGRAPHY}

Amiti, M. and Weinstein, D. E. (2011), 'Exports and Financial Shocks', The Quarterly Journal of Economics 126(4): 1841-1877.

Auboin, M. and Engemann, M. (2014), ' Testing the trade credit and trade link: evidence from data on export credit insurance', Review of World Economics, Volume 150, Issue 4, pp 715-743

Bank of International Settlements (BIS) (2014) Trade Finance, Developments and Issues, CGFS Paper No. 50 Basel: Bank of International Settlements.

Berne Union (2010) Credit Insurance in Support of International Trade: Observations Throughout the Crisis, London: Berne Union.

Bricogne, J.-C., Fontagné, L., Gaulier, G., Taglioni, D. and Vicard, V. (2012), 'Firms and the Global Crisis: French Exports in the Turmoil', Journal of International Economics 87(1): 134-146.

Demirgüc-Kunt, A. and Maksimovic, V. (2002), 'Funding Growth in Bank-Based and Market-Based Financial Systems: Evidence From Firm Level Data', Journal of Financial Economics 65(3).

Eaton, J., Kortum, S., Neiman, B. and Romalis, J. (2011), 'Trade and the Global Recession',

Egger, P. and Url, T. (2006), 'Public Export Credit Guarantees and Foreign Trade Structure: Evidence From Austria', The World Economy 29(4): 399-418.

Felbermayr, G., Heiland, I. and Yalcin, E. (2012), 'Mitigating Liquidity Constraints: Public Export Credit Guarantees in Germany',

Felbermayr, G. and Yalcin, E. (2013), 'Export Credit Guarantees and Export Performance: An Empirical Analysis for Germany', The World Economy 36(8): 967-999.

Hanneman, R. A. and Riddle, M. (2005), Introduction to Social Network Methods, Riverside, CA: University of California Riverside.

International Chamber of Commerce (ICC) (2015) 2015 Rethinking Trade \& Finance: An ICC Private Sector Development Perspective, Paris: International Chamber of Commerce.

Klapper, L. (2006), 'The Role Of Factoring For Financing Small And Medium Enterprises', Journal of Banking \& Finance 30(11): 3111-3130.

Manova, K. (2013), 'Credit Constraints, Heterogeneous Firms, and International Trade', The Review of Economic Studies 80: 711-744.

McMillan, J. and Woodruff, C. (1999), 'Interfirm Relationships and Informal Credit in Vietnam', The Quarterly Journal of Economics 114(4): 1285-1320.

Moser, C., Nestmann, T. and Wedow, M. (2008), 'Political Risk and Export Promotion: Evidence From Germany', The World Economy 31(6): 781-803.

Muschella, D. (2003) The Italian Factoring Industry.

Petersen, M. A. and Rajan, R. (1997), 'Trade Credit: Theories and Evidence', Review of Financial Studies 10(3): 661-691. 
Smith, J. K. and Schnucker, C. (1994), 'An Empirical Examination of Organizational Structure: The Economics of the Factoring Decision', Journal of Corporate Finance 1(1): 119-138.

Sopranzetti, B. J. (1998), 'The Economics of Factoring Accounts Receivable', Journal of Economics \& Business 50: 339-359.

Sopranzetti, B. J. (1999), 'Selling Accounts Receivable and the Underinvestment Problem', The Quarterly Review of Economics and Finance 39(2): 291-301.

Soufani, K. (2002), 'On the Determinants of Factoring As a Financing Choice: Evidence From the UK', Journal of Economics \& Business 54(2): 239-252.

Yi, K.-M. (2003), 'Can Vertical Specialization Explain the Growth of World Trade?', Journal of Political Economy 111(1): 52-102. 
Table A.1

\begin{tabular}{|c|c|c|c|c|c|c|c|c|}
\hline Country & $\begin{array}{l}\text { World Bank } \\
\text { Classification }\end{array}$ & $\begin{array}{c}\text { SME } \\
\text { percentage of } \\
\text { trade }\end{array}$ & $\begin{array}{c}2009 \\
\text { Factoring } \\
\text { (millions } \\
\text { USD) }\end{array}$ & $\begin{array}{l}2010 \\
\text { Factoring } \\
\text { (millions } \\
\text { USD) }\end{array}$ & $\begin{array}{c}2011 \\
\text { Factoring } \\
\text { (millions } \\
\text { USD) }\end{array}$ & $\begin{array}{l}2012 \\
\text { Factoring } \\
\text { (millions } \\
\text { USD) }\end{array}$ & $\begin{array}{l}2013 \\
\text { Factoring } \\
\text { (millions } \\
\text { USD) }\end{array}$ & $\begin{array}{c}2014 \\
\text { Factoring } \\
\text { (millions } \\
\text { USD) }\end{array}$ \\
\hline Argentina & High income: nonOECD & $11 \%$ & 9 & 38 & 44 & 28 & 36 & 73 \\
\hline Australia & High income: OECD & $58 \%$ & 26 & 99 & 107 & 109 & 124 & 60 \\
\hline Austria & High income: OECD & $44 \%$ & 1,720 & 1,694 & 1,530 & 2,523 & 4,253 & 6,557 \\
\hline Belgium & High income: OECD & $44 \%$ & 7,463 & 9,328 & 10,725 & 11,329 & 11,973 & 12,104 \\
\hline Brazil & Upper middle income & $11 \%$ & 44 & 63 & 60 & 74 & 70 & 74 \\
\hline Bulgaria & Upper middle income & $44 \%$ & 90 & 194 & 335 & 426 & 448 & 427 \\
\hline Canada & High income: OECD & $40 \%$ & 599 & 1,003 & 2,163 & 1,456 & 1,714 & 3,271 \\
\hline Chile & High income: OECD & $15 \%$ & 511 & 553 & 1,745 & 2,056 & 1,387 & 802 \\
\hline China & Upper middle income & $68 \%$ & 30,783 & 42,637 & 72,845 & 123,353 & 142,309 & 191,683 \\
\hline Colombia & Upper middle income & $9 \%$ & 71 & 37 & 58 & 51 & 64 & 71 \\
\hline Croatia & High income: nonOECD & $44 \%$ & 41 & 44 & 33 & 39 & 55 & 46 \\
\hline Cyprus & High income: nonOECD & $70 \%$ & 56 & 63 & 81 & 40 & 21 & 21 \\
\hline Czech Republic & High income: OECD & $23 \%$ & 542 & 657 & 1,144 & 1,288 & 8,060 & 1,580 \\
\hline Denmark & High income: OECD & $37 \%$ & 945 & 554 & 495 & 493 & 575 & 1,085 \\
\hline Estonia & High income: OECD & $68 \%$ & 294 & 310 & 188 & 511 & 715 & 809 \\
\hline Finland & High income: OECD & $26 \%$ & 786 & 1,214 & 2,009 & 2,673 & 2,940 & 4,156 \\
\hline France & High income: OECD & $38 \%$ & 16,644 & 23,580 & 26,953 & 33,413 & 28,491 & 21,125 \\
\hline Germany & High income: OECD & $29 \%$ & 18,854 & 7,346 & 11,471 & 9,574 & 10,917 & 12,917 \\
\hline Greece & High income: OECD & $58 \%$ & 1,278 & 2,087 & 2,753 & 2,022 & 2,485 & 2,880 \\
\hline Hong Kong & High income: nonOECD & $68 \%$ & 9,833 & 11,103 & 15,246 & 22,009 & 23,542 & 27,813 \\
\hline Hungary & High income: OECD & $24 \%$ & 181 & 214 & 404 & 319 & 313 & 265 \\
\hline India & Lower middle income & $40 \%$ & 175 & 2,271 & 559 & 272 & 147 & 1,114 \\
\hline Indonesia & Lower middle income & $16 \%$ & - & - & 4 & 4 & 14 & 14 \\
\hline Italy & High income: OECD & $52 \%$ & 14,553 & 20,580 & 35,310 & 41,231 & 43,712 & 41,161 \\
\hline
\end{tabular}




\begin{tabular}{|c|c|c|c|c|c|c|c|c|}
\hline Korea & High income: OECD & $41 \%$ & 1,332 & 2,287 & 3,641 & 4,784 & 4,954 & 6,830 \\
\hline Latvia & High income: nonOECD & $69 \%$ & 1 & 4 & 7 & 7 & 24 & 27 \\
\hline Lithuania & High income: nonOECD & $46 \%$ & 300 & 230 & 286 & 31 & 32 & 427 \\
\hline Luxembourg & High income: OECD & $50 \%$ & 261 & 193 & - & 175 & 166 & 207 \\
\hline Malaysia & Upper middle income & $19 \%$ & 20 & 50 & 167 & 327 & 358 & 473 \\
\hline Malta & High income: nonOECD & $51 \%$ & 25 & 41 & 101 & 164 & 95 & 196 \\
\hline Morocco & Lower middle income & $30 \%$ & 155 & 139 & 127 & 124 & 123 & 106 \\
\hline Netherlands & High income: OECD & $47 \%$ & 9,760 & 10,527 & 12,328 & 12,287 & 13,809 & 8,803 \\
\hline Norway & High income: OECD & $44 \%$ & 1,282 & 1,553 & 1,669 & 1,730 & 2,499 & 1,504 \\
\hline Poland & High income: OECD & $29 \%$ & 1,983 & 2,174 & 1,732 & 1,924 & 2,243 & 3,234 \\
\hline Portugal & High income: OECD & $46 \%$ & 1,185 & 1,501 & 1,579 & 1,479 & 1,366 & 1,406 \\
\hline Romania & Upper middle income & $34 \%$ & 289 & 690 & 945 & 894 & 786 & 898 \\
\hline Russia & High income: nonOECD & $50 \%$ & 103 & 102 & 325 & 489 & 941 & 616 \\
\hline Serbia & Upper middle income & $44 \%$ & 38 & 67 & 80 & 47 & 46 & 55 \\
\hline Singapore & High income: nonOECD & $20 \%$ & 9,422 & 4,622 & 5,489 & 6,496 & 14,025 & 13,603 \\
\hline Slovakia & High income: OECD & $34 \%$ & 60 & 78 & 151 & 177 & 244 & 207 \\
\hline Slovenia & High income: OECD & $39 \%$ & 108 & 131 & 146 & 186 & 173 & 158 \\
\hline Spain & High income: OECD & $46 \%$ & 11,302 & 14,303 & 18,448 & 18,149 & 18,729 & 28,548 \\
\hline Sweden & High income: OECD & $37 \%$ & - & - & - & - & - & - \\
\hline Thailand & Upper middle income & $46 \%$ & 40 & 32 & 14 & 69 & 92 & 58 \\
\hline Turkey & Upper middle income & $56 \%$ & 3,123 & 4,507 & 7,428 & 7,638 & 8,109 & 10,279 \\
\hline Ukraine & Lower middle income & $50 \%$ & 8 & 12 & 14 & 11 & 21 & 16 \\
\hline United Kingdom & High income: OECD & $37 \%$ & 9,533 & 9,359 & 11,040 & 13,833 & 16,444 & 15,091 \\
\hline United States & High income: OECD & $20 \%$ & 8,224 & 9,018 & 12,057 & 13,858 & 17,679 & 17,380 \\
\hline Vietnam & Lower middle income & $20 \%$ & 5 & 6 & 7 & 6 & 57 & 106 \\
\hline Total & & & $\$ 164,057$ & $\$ 187,295$ & $\$ 264,042$ & $\$ 340,178$ & $\$ 387,377$ & $\$ 440,337$ \\
\hline
\end{tabular}




\section{Table A.2}

\begin{tabular}{|c|c|c|c|c|c|c|c|c|}
\hline & & & 2009 & 2010 & 2011 & 2012 & 2013 & 2014 \\
\hline Country & $\begin{array}{l}\text { World Bank } \\
\text { Classification }\end{array}$ & $\begin{array}{l}\text { SME percentage } \\
\text { of trade }\end{array}$ & $\begin{array}{l}\text { SME } \\
\text { contribution } \\
\text { to trade } \\
\text { (millions } \\
\text { USD) }\end{array}$ & $\begin{array}{l}\text { SME } \\
\text { contribution } \\
\text { to trade } \\
\text { (millions } \\
\text { USD) }\end{array}$ & $\begin{array}{l}\text { SME } \\
\text { contribution } \\
\text { to trade } \\
\text { (millions } \\
\text { USD) }\end{array}$ & $\begin{array}{l}\text { SME } \\
\text { contribution } \\
\text { to trade } \\
\text { (millions } \\
\text { USD) }\end{array}$ & $\begin{array}{l}\text { SME } \\
\text { contribution } \\
\text { to trade } \\
\text { (millions } \\
\text { USD) }\end{array}$ & $\begin{array}{l}\text { SME } \\
\text { contribution } \\
\text { to trade } \\
\text { (millions } \\
\text { USD) }\end{array}$ \\
\hline Argentina & $\begin{array}{l}\text { High income: } \\
\text { nonOECD }\end{array}$ & $11 \%$ & 5,195 & 6,874 & 8,710 & 8,155 & 8,542 & 7,552 \\
\hline Australia & High income: OECD & $58 \%$ & 92,902 & 120,346 & 149,734 & 150,367 & 143,833 & 138,900 \\
\hline Austria & High income: OECD & $44 \%$ & 61,611 & 68,545 & 81,146 & 75,927 & 78,855 & 79,159 \\
\hline Belgium & High income: OECD & $44 \%$ & 159,168 & 175,751 & 207,375 & 194,715 & 202,496 & 203,250 \\
\hline Brazil & Upper middle income & $11 \%$ & 15,050 & 20,656 & 25,883 & 24,989 & 25,861 & 24,373 \\
\hline Bulgaria & Upper middle income & $44 \%$ & 8,769 & 10,151 & 13,374 & 13,067 & 14,054 & 14,098 \\
\hline Canada & High income: OECD & $40 \%$ & 129,523 & 158,429 & 183,452 & 186,572 & 186,990 & 190,417 \\
\hline Chile & High income: OECD & $15 \%$ & 7,370 & 9,774 & 11,710 & 11,840 & 11,679 & 11,088 \\
\hline China & Upper middle income & $68 \%$ & 750,562 & $1,011,160$ & $1,238,234$ & $1,314,820$ & $1,414,058$ & $1,462,565$ \\
\hline Colombia & Upper middle income & $9 \%$ & 2,959 & 3,609 & 5,002 & 5,363 & 5,319 & 5,347 \\
\hline Croatia & $\begin{array}{l}\text { High income: } \\
\text { nonOECD }\end{array}$ & $44 \%$ & 6,936 & 7,012 & 7,920 & 7,305 & 7,630 & 8,063 \\
\hline Cyprus & $\begin{array}{l}\text { High income: } \\
\text { nonOECD }\end{array}$ & $70 \%$ & 3,182 & 3,490 & 3,673 & 3,162 & 2,917 & 2,992 \\
\hline Czech Republic & High income: OECD & $23 \%$ & 25,070 & 29,858 & 36,232 & 34,322 & 35,251 & 37,529 \\
\hline Denmark & High income: OECD & $37 \%$ & 32,767 & 33,206 & 38,393 & 36,518 & 38,239 & 38,919 \\
\hline Estonia & High income: OECD & $68 \%$ & 6,524 & 8,118 & 11,617 & 11,619 & 11,823 & 11,670 \\
\hline Finland & High income: OECD & $26 \%$ & 16,087 & 17,982 & 21,243 & 19,441 & 19,761 & 19,625 \\
\hline France & High income: OECD & $38 \%$ & 198,674 & 215,619 & 250,135 & 236,193 & 239,862 & 239,456 \\
\hline Germany & High income: OECD & $29 \%$ & 296,726 & 335,492 & 395,684 & 372,407 & 383,290 & 394,871 \\
\hline Greece & High income: OECD & $58 \%$ & 26,076 & 27,510 & 29,375 & 28,644 & 28,642 & 28,868 \\
\hline
\end{tabular}




\begin{tabular}{|c|c|c|c|c|c|c|c|c|}
\hline Hong Kong & $\begin{array}{l}\text { High income: } \\
\text { nonOECD }\end{array}$ & $68 \%$ & 231,765 & 286,301 & 328,586 & 355,774 & 393,245 & 382,391 \\
\hline Hungary & High income: OECD & $24 \%$ & 19,292 & 22,039 & 25,770 & 23,849 & 24,914 & 25,886 \\
\hline India & Lower middle income & $40 \%$ & 84,422 & 115,317 & 153,473 & 157,304 & 156,049 & 156,926 \\
\hline Indonesia & Lower middle income & $16 \%$ & - & 23,475 & 30,475 & 30,538 & 29,534 & 28,358 \\
\hline Italy & High income: OECD & $52 \%$ & 213,724 & 242,931 & 281,332 & 257,375 & 259,406 & 260,132 \\
\hline Korea & High income: OECD & $41 \%$ & 140,757 & 182,777 & 221,324 & 218,828 & 220,419 & 225,126 \\
\hline Latvia & $\begin{array}{l}\text { High income: } \\
\text { nonOECD }\end{array}$ & $69 \%$ & 6,042 & 7,322 & 10,150 & 10,812 & 11,154 & 11,124 \\
\hline Lithuania & $\begin{array}{l}\text { High income: } \\
\text { nonOECD }\end{array}$ & $46 \%$ & 7,994 & 10,155 & 13,759 & 14,162 & 15,503 & 15,562 \\
\hline Luxembourg & High income: OECD & $50 \%$ & 11,667 & 11,210 & 12,432 & 11,594 & 11,344 & 11,476 \\
\hline Malaysia & Upper middle income & $19 \%$ & 26,695 & 34,507 & 39,478 & 40,273 & 41,252 & 42,085 \\
\hline Malta & $\begin{array}{l}\text { High income: } \\
\text { nonOECD }\end{array}$ & $51 \%$ & 1,870 & 2,205 & 2,723 & 2,766 & 2,494 & 2,372 \\
\hline Morocco & Lower middle income & $30 \%$ & 7,040 & 7,973 & 9,889 & 9,948 & 10,074 & 10,424 \\
\hline Netherlands & High income: OECD & $47 \%$ & 221,145 & 256,305 & 296,445 & 291,941 & 296,394 & 296,033 \\
\hline Norway & High income: OECD & $44 \%$ & 40,865 & 45,757 & 55,263 & 54,617 & 53,725 & 51,277 \\
\hline Poland & High income: OECD & $29 \%$ & 41,464 & 48,977 & 57,898 & 55,743 & 59,826 & 63,294 \\
\hline Portugal & High income: OECD & $46 \%$ & 26,651 & 29,246 & 32,778 & 30,019 & 31,865 & 32,704 \\
\hline Romania & Upper middle income & $34 \%$ & 16,131 & 18,987 & 23,718 & 21,768 & 23,673 & 25,077 \\
\hline Russia & $\begin{array}{l}\text { High income: } \\
\text { nonOECD }\end{array}$ & $50 \%$ & 123,798 & 162,316 & 211,461 & 216,175 & 216,153 & 201,448 \\
\hline Serbia & Upper middle income & $44 \%$ & 5,366 & 5,836 & 6,961 & 6,634 & 7,736 & 7,799 \\
\hline Singapore & $\begin{array}{l}\text { High income: } \\
\text { nonOECD }\end{array}$ & $20 \%$ & 51,562 & 66,266 & 77,527 & 78,812 & 78,327 & 77,602 \\
\hline Slovakia & High income: OECD & $34 \%$ & 18,994 & 22,047 & 27,144 & 26,862 & 28,472 & 28,681 \\
\hline Slovenia & High income: OECD & $39 \%$ & 10,273 & 11,562 & 13,692 & 12,518 & 13,142 & 13,690 \\
\hline Spain & High income: OECD & $46 \%$ & 119,728 & 133,730 & 157,126 & 145,495 & 151,439 & 157,173 \\
\hline Sweden & High income: OECD & $37 \%$ & 46,371 & 56,887 & - & - & - & - \\
\hline
\end{tabular}




\begin{tabular}{|c|c|c|c|c|c|c|c|c|}
\hline Thailand & Upper middle income & $46 \%$ & 65,810 & 86,532 & 103,813 & 109,991 & 110,150 & 104,771 \\
\hline Turkey & Upper middle income & $56 \%$ & 68,060 & 83,840 & 105,210 & 108,922 & 112,970 & 111,942 \\
\hline Ukraine & Lower middle income & $50 \%$ & 21,317 & 28,097 & 37,764 & 38,292 & 35,281 & 27,132 \\
\hline $\begin{array}{l}\text { United } \\
\text { Kingdom }\end{array}$ & High income: OECD & $37 \%$ & 161,685 & 186,305 & 218,941 & 215,344 & 221,416 & 220,117 \\
\hline United States & High income: OECD & $20 \%$ & 263,473 & 321,520 & 371,105 & 384,340 & 386,957 & 399,275 \\
\hline Vietnam & Lower middle income & $20 \%$ & 12,705 & 15,708 & 20,366 & 22,831 & 26,407 & 29,974 \\
\hline Total & & & $\$ 3,911,820$ & $\$ 4,789,714$ & $\$ 5,665,492$ & $\$ 5,688,956$ & $\$ 5,888,422$ & $\$ 5,938,590$ \\
\hline
\end{tabular}

\section{Table A.3}

\begin{tabular}{|c|c|c|c|c|c|c|}
\hline \multirow{6}{*}{$\begin{array}{c}\text { Log } \\
\text { (Factoring) }\end{array}$} & Top \% & $20 \%$ & $40 \%$ & $60 \%$ & $\begin{array}{c}\text { og (SME Trade) } \\
\mathbf{8 0 \%}\end{array}$ & $100 \%$ \\
\hline & $20 \%$ & $\begin{array}{l}\text { Pairs: } 86 \\
\text { Obs: } 326\end{array}$ & $\begin{array}{l}\text { Pairs: } 131 \\
\text { Obs: } 493\end{array}$ & $\begin{array}{l}\text { Pairs: } 165 \\
\text { Obs: } 625\end{array}$ & $\begin{array}{l}\text { Pairs: } 184 \\
\text { Obs: } 677\end{array}$ & Pairs: 194 obs: 701 \\
\hline & $40 \%$ & $\begin{array}{l}\text { Pairs: } 119 \\
\text { Obs: } 494\end{array}$ & $\begin{array}{l}\text { Pairs: } 211 \\
\text { Obs: } 844\end{array}$ & $\begin{array}{l}\text { Pairs: } 281 \\
\text { Obs: } 1,126\end{array}$ & $\begin{array}{l}\text { Pairs: } 342 \\
\text { Obs: } 1,336\end{array}$ & Pairs: 385 Obs: 1,476 \\
\hline & $60 \%$ & $\begin{array}{l}\text { Pairs: } 146 \\
\text { Obs: } 609\end{array}$ & $\begin{array}{l}\text { Pairs: } 275 \\
\text { Obs: } 1,112\end{array}$ & $\begin{array}{l}\text { Pairs: } 380 \\
\text { Obs: } 1,563\end{array}$ & $\begin{array}{l}\text { Pairs: } 495 \\
\text { Obs: } 1,953\end{array}$ & Pairs: 579 Obs: 2,240 \\
\hline & $80 \%$ & $\begin{array}{l}\text { Pairs: } 163 \\
\text { Obs: } 700\end{array}$ & $\begin{array}{l}\text { Pairs: } 329 \\
\text { Obs: } 1,349\end{array}$ & $\begin{array}{l}\text { Pairs: } 470 \\
\text { Obs 1,962 }\end{array}$ & $\begin{array}{l}\text { Pairs: } 636 \\
\text { Obs 2,535 }\end{array}$ & Pairs: 786 Obs: 3,010 \\
\hline & $100 \%$ & $\begin{array}{l}\text { Pairs: } 172 \\
\text { Obs: } 760\end{array}$ & $\begin{array}{l}\text { Pairs: } 356 \\
\text { Obs: } 1,522\end{array}$ & $\begin{array}{l}\text { Pairs: } 523 \\
\text { Obs: } 2,280\end{array}$ & $\begin{array}{l}\text { Pairs: } 730 \\
\text { Obs: } 3,038\end{array}$ & Pairs: 994 Obs: 3,795 \\
\hline
\end{tabular}


Table A.4: Unit Root Tests of Stationarity

Fisher-type unit-root test for $\mathrm{Ln}$ (SME Trade)

Based on augmented Dickey-Fuller tests

Ho: All panels contain unit roots Number of panels $=52$

Ha: At least one panel is stationary Avg. number of periods $=5.67$

AR parameter: Panel-specific Asymptotics: T -> Infinity

Panel means: Included

Time trend: Included

Drift term: Not included ADF regressions: 0 lags

Statistic p-value

Inverse chi-squared(98) P 123.42930 .0422

Inverse normal Z 4.13411 .0000

Inverse logit $\mathrm{t}(244) \mathrm{L} * 2.30850 .9891$

Modified inv. chi-squared Pm 1.81640 .0347

P statistic requires number of panels to be finite.

Other statistics are suitable for finite or infinite number of panels.

Fisher-type unit-root test for $\operatorname{Ln}$ (Factoring)

Based on augmented Dickey-Fuller tests

Ho: All panels contain unit roots Number of panels $=73$

Ha: At least one panel is stationary Avg. number of periods $=5.25$

AR parameter: Panel-specific Asymptotics: T -> Infinity

Panel means: Included

Time trend: Included

Drift term: Not included ADF regressions: 0 lags

Statistic p-value

Inverse chi-squared(130) P 284.6074 0.0000

Inverse normal Z 0.56130 .7127

Inverse logit $\mathrm{t}(284) \mathrm{L} *-3.07560 .0012$ 


\begin{tabular}{|l|}
\hline Modified inv. chi-squared Pm 9.58830 .0000 \\
\hline P statistic requires number of panels to be finite. \\
Other statistics are suitable for finite or infinite number of panels. \\
\hline
\end{tabular}

Fisher-type unit-root test for $\operatorname{Ln}($ Credit)

Based on augmented Dickey-Fuller tests

\begin{tabular}{|c|c|c|}
\hline Ho: All panels contain unit roots & Number of panels $=$ & 79 \\
\hline Ha: At least one panel is stationary & Avg. number of periods $=$ & 5.37 \\
\hline AR parameter: Panel-specific & Asymptotics: T -> Infinity & \\
\hline Panel means: Included & & \\
\hline Time trend: Included & & \\
\hline Drift term: Not included & ADF regressions: 0 lags & \\
\hline Statistic & p-value & \\
\hline Inverse chi-squared(146) P 469.0736 & 0.0000 & \\
\hline Inverse normal Z -3.7214 & 0.0001 & \\
\hline Inverse logit $\mathrm{t}(314) \mathrm{L}^{*}-10.3248$ & 0.0000 & \\
\hline Modified inv. chi-squared Pm 18.9065 & 0.0000 & \\
\hline
\end{tabular}

Fisher-type unit-root test for Ln(Delays)

Based on augmented Dickey-Fuller tests

Ho: All panels contain unit roots Number of panels =

Ha: At least one panel is stationary Avg. number of periods $=4.87$

AR parameter: Panel-specific Asymptotics: T -> Infinity

Panel means: Included

Time trend: Included

Drift term: Not included ADF regressions: 0 lags

Statistic p-value 
Inverse chi-squared(112) P 366.94190 .0000

Inverse normal Z -3.41360.0003

Inverse logit $\mathrm{t}(239) \mathrm{L} *-9.37850 .0000$

Modified inv. chi-squared Pm 17.03400 .0000 
Table A.5: Granger Causality Tests

Table X: Testing endogeneity of factoring: Granger causality tests

\begin{tabular}{|l|c|c|}
\hline \multicolumn{1}{|c|}{ Explanatory Variables } & chi2 Statistic & $\operatorname{Prob}[\chi 2>$ chi2] \\
\hline $\mathrm{dLn}$ (Factoring) & 1.925 & 0.165 \\
\hline $\mathrm{dLn}($ Credit $)$ & 1.227 & 0.268 \\
\hline
\end{tabular}

